\title{
TERAPI DZIKIR DAN MUROTTAL UNTUK MENGURANGI KECEMASAN PADA PRE EKLAMPSIA RINGAN
}

\author{
Anita Widiastuti*1); Rusmini; Siti Mulidah; Welas Haryati \\ 1)Jurusan Kebidanan ; Poltekkes Kemenkes Semarang \\ Jl. Tirto Agung ; Pedalangan ; Banyumanik ; Semarang ; Jawa Tengah ; Indonesia
}

\begin{abstract}
Abstrak
Kematian ibu masih menjadi masalah besar di negara berkembang. Tiga penyebab utama kematian ibu di Banyumas adalah preeklamsia. Pre-eklampsia adalah kumpulan gejala yang terjadi pada kehamilan, persalinan, postpartum yang terdiri dari hipertensi dan proteinuria. Studi tersebut mengatakan bahwa kecemasan berhubungan dengan preeklamsia. Penelitian ini menggunakan desain Pra-eksperimen Pretest-PostestControlGroup. Pengukuran faktor risiko (kecemasan) menggunakan kuesioner T-MAS (Taylor Manifest Anxiety Scale) Responden yang berpartisipasi sebanyak 40. Uji statistik nilai z ingat relaksasi dihitung sebesar 3,923 dan p-value 0,0001. Statistic murottal therapy Nilai Z dihitung pada 3,927 dan p-value 0,0001. Uji beda dhikr relaksasi sedikit pun terapi murottal diperoleh p-value 0,004. Kesimpulan Relaksasi dhikr mampu mengurangi kecemasan pada responden. Terapi murottal juga mampu mengurangi kecemasan responden. Relaksasi dhikr memiliki keefektifan yang lebih baik dalam mengurangi kecemasan dengan melihat $\mathrm{p}$-value dan mean yang berbeda. Klien yang intervensinya menuntut aktivitas sesuai dengan kemampuan mereka memiliki kekuatan dan motivasi internal yang kuat.
\end{abstract}

Kata kunci: Preeklampsia; T-MAS (Taylor Manifest Anxiety Scale); Terpai Dzikir dan Murrottal

\begin{abstract}
[DHIKR AND MUROTTAL THERAPY TO DECREASE ANXIETY IN PREGNANT WITH LOW PRE ECLAMPSIA] Maternal death is still a major problem in developing countries. The three major causes of maternal deaths in Banyumas one is preeclampsia. Pre-eclampsia is a collection of symptoms that occur in pregnancy, childbirth, postpartum consisting of hypertension and proteinuria. The study says that the anxiety associated with preeclampsia. This study uses the Pre-experiment design Pretest-PostestControlGroup. Measurement of risk factors (anxiety) used a questionnaire T-MAS (Taylor Manifest Anxiety Scale) Respondents who participated as much as 40. Test statistic relaxation remembrance $Z$ value calculated at 3.923 and p-value 0,0001 . Statistic murottal therapy $Z$ value calculated at 3.927 and p-value of 0.0001 . Different test dhikr relaxation whit therapy murottal obtained the p-value of 0.004 . Conclusion Relaxation dhikr able to reduce anxiety in respondent. Terapi murottal also able to reduce the anxiety of respondents. Relaxation dhikr has better effectiveness in reducing anxiety by looking at different $p$-value and mean. Clients whose intervention demands activities according to their abilities have strong internal strength and motivation.
\end{abstract}

Keywords: Preeclampsia; Anxiety; T-MAS (Taylor Manifest Anxiety Scale); Dhikr And Murottal Therapy

\section{Pendahuluan}

Wanita merupakan pilar utama dalam keluarga yang berperan penting dalam mendidik

*) Correspondence author (Anita Widiastuti)

E-mail: a.widiastuti@yahoo.co.id anak - anak, memberikan perawatan kesehatan dalam keluarga dan membantu perekonomian keluarga. Berdasarkan Survei Demografi Kesehatan Indonesia (SDKI) tahun 2012, Angka Kematian Ibu sebesar 359 per 100.000 kelahiran 
hidup. Hasil ini meningkat dibandingkan dengan periode survey sebelumnya pada tahun 2007 dimana AKI sebesar 228 per 100.000 kelahiran hidup.

Data dari Dinas Kesehatan Propinsi Jawa Tengah menyebutkan bahwa AKI di Jawa Tengah pada tahun 2014 sebesar 126.55. Angka ini meningkat bila dibandingkan tahun 2013 yaitu 118,62. Di Kabupaten Banyumas untuk tahun 2015 kasus kematian ibu tercatat 29 kasus. Jumlah ini mengalami sedikit penurunan dari tahun 2014 yang mencapai 33 kasus kematian ibu. Penyebab kematian ibu yang dahulu didominasi akibat perdarahan, saat ini penyebabnya sudah di ambil alih oleh pre eklamsia dan eklamsia.

Kematian ibu di Indonesia didominasi oleh tiga penyebab kematian utama yaitu perdarahan $30,3 \%$, hipertensi dalam kehamilan (HDK) 27,2\% dan infeksi sebanyak 7,3\%. Namun secara nasional proporsi mulai berubah dimana kematian yang disebabkan perdarahan dan infeksi kasusnya cenderung menurun, sedangkan kematian yang diakibatkan HDK proporsinya semakin meningkat (Kemenkes RI, 2015).

Menurut penelitian yang dilakukan Mardiyono Songwathana \& Petpichetchian, (2011) relaksasi dzikir mampu mengurangi kecemasan pasien AMI. Relaksasi yang dilakukan mampu menimbulkan respon relaksasi berupa perasaan nyaman dengan indikator perubahan secara klinis berupa: penurunan tekanan darah, respirasi dan konsumsi oksigen (Potter \& Perry, 2006).

Kecemasan juga bisa diturunkan menggunakan teknik murottal. Hal ini telah diteliti oleh Riza Wahyuni (2013) juga oleh Rohmi Handayani (2014). Hasil penelitian menunjukkan bahwa ibu hamil yang mengalami kecemasan saat menghadapi persalinan mengalami penurunan tingkat kecemasan yang singnifikant. Tujuan penelitian adalah mengetahui efektifitas relaksasi dzikir dibandingkan dengan terapi murottal dalam menurunkan tingkat kecemasan pada ibu hamil dengan pre eklpamsia

Preeklampsia adalah timbulnya hipertensi disertai proteinuria dan oedema akibat kehamilan setelah 20 minggu atau segera setelah persalinan (Mansjoer, 2007; Milne et al., 2005). Menurut Cunningham et al. (2005), preeklampsia adalah sindrom spesifik yang terjadi pada kehamilan berupa berkurangnya perfusi organ akibat vasospasme dan aktivasi endotel. Proteinuria atau terdapatnya $30 \mathrm{mg}$ atau lebih protein dalam urin per 24 jam merupakan tanda yang pasti untuk ditegakkan diagnosis preeklampsia.

Menurut Mansjoer (2007), preeklampsia dibedakan menjadi dua berdasarkan tanda dan gejala sebagai berikut : Preeklampsia ringan tanda dan gejala yang muncul pada preeklampsia ringan adalah sebagai berikut : tekanan darah $140 / 90 \mathrm{mmHg}$ atau lebih yang diukur pada posisi berbaring terlentang atau kenaikan sistolik $30 \mathrm{mmHg}$ atau lebih. Cara pengukuran sekurang-kurangnya pada dua kali pemeriksaan dengan jarak periksa satu jam, sebaiknya 6 jam. Oedema umum, kaki jari tangan, dan muka atau kenaikan berat badan satu kilogram atau lebih per minggu. Proteinuria kuantitatif 0,3 gr atau lebih per liter, kualitatif +1 atau +2 pada urin midstream .

Beberapa landasan teori dikemukakan oleh Manuaba (2007), sebagai berikut: Teori genetic, berdasarkan teori ini, komplikasi hipertensi pada kehamilan dapat diturunkan pada anak perempuanya sehingga sering terjadi hipertensi sebagai komplikasi kehamilannya. Sifat herediternya adalah "resesif" sehingga tidak atau jarang terjadi pada menantunya. Kejadian hipertensi pada kehamilan berikutnya atau ketiga akan semakin berkurang.

Teori immunologis, hasil konsepsi merupakan allegraf atau benda asing tidak murni karena sebagian genetiknya berasal dari sel maternal, sehingga sebagian besar kehamilan berhasil dengan baik sampai aterm. Unsur benda asing hanya berasal dari pihak suami sehingga terdapat beberapa kemungkinan terhadap hasil konsepsi. Karena kegagalan invasi migrasi, sel trofoblas masuk jauh ke dalam pembuluh darah arterioli yang berada dalam miometrium. Hal ini dapat menyebabkan arterioli tidak dipengaruhi oleh sistem hormonal plasenta untuk dapat mendukung tumbuh kembang janin dalam rahim sehingga ada kemungkinan terjadi kegagalan dalam distribusi nutrisi yang menimbulkan intrauterine growth retardation (IUGR). Bila terjadi iskemia regio uteroplasenter, dapat menimbulkan hipertensi dalam kehamilan. Berat ringannya komplikasi IUGR dan hipertensi dalam kehamilan bergantung pada jumlah dan kualitas lumen arterioli dalam miometrium yang gagal mengalami proses invasi oleh sel trofoblas.

Teori iskemia regio uteroplasenter, Williams dikutip oleh Manuaba (2007) melaporkan dan mengemukakan hipotesis tentang hipertensi pada kehamilan yang menyatakan bahwa terdapat "toksin" yang menyebabkan terjadinya gejala preeklampsia dan eklampsia. Dugaan tersebut ada benarnya 
mengingat saat itu belum dilakukan penelitian yang menemukan penyebab pastinya.

Kejadian preeklampsia yang bervariasi untuk setiap negara bahkan pada setiap daerah juga dijelaskan oleh (Manuaba, 2007). Menurut Sarwono (2008) hal ini disebabkan oleh berbagai faktor yang mempengaruhi diantaranya: primigravida, terutama primigravida muda, distensi rahim berlebihan/hidramnion, hamil ganda, mola hidatidosa, penyakit yang menyertai hamil seperti diabetes mellitus, hipertensi, penyakit ginjal, umur ibu diatas 35 tahun (Manuaba, 2007 dan Miller, 2007).

Kecemasan (ansietas) adalah gangguan alam perasaan (affective) yang ditandai dengan perasaan ketakutan atau kekhawatiran yang mendalam dan berkelanjutan, tidak mengalami gangguan dalam realitas (Reality Testing Ability / RTA, masih baik), kepribadian masih tetap utuh (tidak mengalami keretakan kepribadian/ spliting of personality), perilaku dapat terganggu tapi masih dalam batas-batas normal (Hawari, 2007). Sedangkan menurut Hurlok (1980) Kecemasan adalah keadaan mental yang tidak enak dalam rasa cemas (di tandai oleh kekhawatiran, ketidakenakan dan perasaan tidak berdaya karena merasa menemui jalan buntu dan disertai pula ketidakmampuan menemukan pemecahan masalah yang dihadapi) sehingga pada suatu saat kondisi cemas meningkat menjadi kecemasan.

Setiap perubahan kehidupan yang dapat menimbulkan keadaan stress disebut stressor. Kecemasan adalah merupakan respon individu terhadap suatu keadaan yang tidak menyenangkan, kecemasan pada suami istri yang berkaitan dengan kelahiran termasuk dalam tingkat kecemasan sedang (Suliswati, 2005). Tingkat kecemasan dapat diukur dengan menggunakan skala seperti Hamilton Anxiety Scale, Anxiety Scale dari Datex, Manifest Anxiety Scale dari Taylor dan test Anxiety Questionare dari Jorason. Taylor Manifest Anxiety Scale(T-MAS) diciptakan dan dikembangan oleh Taylor tahun 1953 di Universitas Nortwestrn. Pernyataan dalam T-MAS terdiri dari 50 pertanyaan yang merupakan instrumen yang dipergunakan untuk mengetahui keadaan kecemasan pada seseorang. Tes ini merupakan tes kecemasan standard dan dapat diterima secara internasional.

Penatalaksanaan pada Kecemasan. Salah satu pendekatan keyakinan spiritual dalam agama Islam yaitu dengan teknik mengingat Allah atau berdzikir. Beberapa penelitian menunjukkan efektivitas dzikir terhadap berbagai kondisi dan subjek penelitian, seperti kecemasan pada pasien AMI (Acute Myocardial Infarction) (Mardiyono, Songwathana \& Petpichetchian, 2011), kecemasan pasien pre operasi bedah mayor (Mardiyono, Angraeni, \& Sulistyowati, 2007), kecemasan pasien GGK (Patimah, 2015).

Menurut Maimunnah (2011) Dzikir ialah mengingat nikmat-nikmat Tuhan. Lebih jauh, berdzikir meliputi pengertian menyebut lafal-lafal dzikir dan mengingat Allah dalam setiap waktu, takut dan berharap hanya kepada Tuhan, merasa yakin bahwa diri manusia selalu berada dibawah kehendak Allah dalam segala hal dan urusannya.

Prosedur dzikir menurut Yanti (2012) melalui tahapan sebagai berikut: berwudhu, mencari suasana yang tenang dan duduk dengan rileks, melakukan teknik nafas dalam, melakukan peregangan otot, setelah itu mengucapkan beberapa kalimat dzikir baik secara lisan maupun qolbu (dalam hati) serta diakhiri dengan bacaan Alhamdulillah. Dalam melaksanakan relaksasi dzikir sebetulnya dapat dilaksanakan kapanpun dan tidak ada batasan waktu. Menurut penelitian yang dilakukan Mardiono Songwathana \& Petpichetchian, (2011) pelaksanaan relaksasi dzikir untuk mengurangi kecemasan pasien dilakukan selama 25 menit dengan dzikir "subhanalloh".

Murotal adalah membaca Alqur'an dengan irama sedang, tidak terlalu lambat dan tidak terlalu cepat (tartil) (Wahyuni, 2013). Bacaan Al qur'an terdiri dari dua hal yaitu suara orang yang membaca dan makna yang dikandungnya. Penelitian yang dilakukan Al Kaheel (2012) menemukan bahwa semua sel-sel tubuh dipengaruhi oleh frekuensi akustik (suara) yang kemudian mempengaruhi medan elektromagnetik sel itu. Penelitian ini membuktikan bahwa yang terbaik dan dapat memprogram ulang sel-sel melalui bacaan ayat-ayat $\mathrm{Al}$ qur'an yang shahih, agar sel-sel dapat bergetar dengan frekuensi getaran yang tepat sesuai dengan fitrah Allah SWT.

Lantunan Al-Qur'an secara fisik mengandung unsur suara manusia, suara manusia merupakan instrument penyembuhan yang menakjubkan dan alat yang paling mudah dijangkau. Suara dapat menurunkan hormon-hormon stress, mengaktifkan hormon endorfin alami, meningkatkan perasaan rileks dan mengalihkan perhatian dari rasa takut, cemas dan tegang, memperbaiki sistem kimia tubuh sehingga menurunkan tekanan darah serta memperlambat pernafasan, detak jantung, denyut nadi dan aktivitas gelombang otak. Laju 
pernafasan yang dalam atau lebih lambat tersebut sangat baik menimbulkan ketenangan, kendali emosi, pemikiran yang lebih dalam dan metabolisme yang lebih baik.

Penelitian yang pernah diteliti oleh Handayani, Fajarsari, Asih \& Rohmah menunjukkan bahwa ada perbedaan rerata penurunan tingkat kecemasan pada persalinan kala I fase aktif sebelum dan sesudah dilakukan terapi murottal. Prosedur pemberian terapi murottal adalah, pertama atur pasien pada posisi nyaman, kedua persiapan terapi (handphone dan headset), ketiga memutaran murottal dengan lama tindakan selama 15 menit (Handayani, 2014).

\section{Metode}

Desain yang digunakan dalam penelitian ini yaitu Quasi Eksperiment Pretest-Postest Control Group design yaitu rancangan dengan kelompok pembanding, melakukan observasi pertama (pretest) yang memungkinkan peneliti dapat menguji perubahan-perubahan yang terjadi setelah adanya eksperimen (program).Variabel independen : relaksasi dzikir, terapi murottal dan variabel Dependen adalah tingkat kecemasan.

Populasi adalah ibu hamil yang melakukan ANC di Puskesmas Wilayah Baturraden. Pada bulan Juli 2016 sebanyak 790 ibu. Teknik pengambilan sampel dengan non-probability sampling menggunakan pendekatan purposive sampling berdasarkan ciri ciri populasi yang sudah di ketahui sebelumnya. Besar sampel dalam penelitian ini adalah 40 responden, mengikuti dasar teori central limit theorem (Santjaka, 2011). Kriteria inklusi pada penelitian ini adalah: Ibu hamil primi dengan usia kehamilan 20-37 minggu, ibu beragama Islam, belum ada tanda dan gejala persalinan, telah memeriksakan kehamilannya minimal satu kali, ibu masuk kriteria pre eklampsia ringan: ibu mempunyai tekanan darah $\geq 140 \mathrm{mmHg}$ dan proteinuri minimal +1 .

Definisi Operasional

1. Relaksasi dzikir adalah menyebut lafal-lafal untuk mengingat Alloh dan mengingat Allah dapat dilakukan setiap waktu, takut dan berharap hanya kepada-Nya, merasa yakin bahwa diri manusia selalu berada dibawah kehendak Allah dalam segala hal dan urusannya. Lafal yang di ucapkan adalah Subhanalloh wabihamdihi, subhanalloh hil'azim selama 25 menit.
2. Terapi murottal adalah teknik penyembuhan dengan mendengarkan rekaman bacaan $\mathrm{Al}$ qur'an dengan irama sedang, tidak terlalu lambat dan tidak terlalu cepat. Surat yang digunakan adalah Ar rohman durasi waktu 15 menit.

3. Tingkat kecemasan adalah Suatu kondisi dimana keadaan mental mengalami kekhawatiran, ketidakenakan sehingga dapat mengganggu aktifitas seseorang. Penggukuran dengan kuesioner yang diambil dari modifikasi T-MAS. Skor 0-50 sesuai kuesioner.

Sebelum memberikan perlakuan, peneliti mencari ibu hamil dengan pre eklpamsia ringan. Selanjutnya test awal untuk mengetahui tingkat kecemasan awal. Responden yang bersedia diberi perlakuan sesuai prosedur. Pada tahap akhir dilakukan post test menggunakan pertanyaan-pertanyaan sesuai kuesioner T-MAS.

Analisis univariat dilakukan untuk memperoleh gambaran terhadap masing-masing variabel. Mendiskripsikan semua variabel bebas dan terikat, data disajikan dalam bentuk tabel distribusi frekuensi.

Dalam penelitian ini pengolahan data menggunakan bantuan komputer. Uji statistik menggunakan uji wilcoxon untuk data berpasangan karena sebaran data tidak berdistribusi normal. Tingkat Kepercayaan yang dipakai peneliti adalah 95\%. Beda Efektifitas uji statistik menggunakan uji mann whitney untuk data tidak berpasangan dimana data sebarannya tidak normal. Tingkat Kepercayaan yang dipakai peneliti adalah $95 \%$, berarti derajat kesalahannya $5 \%$.

\section{Hasil dan Pembahasan}

Hasil

Penelitian telah di lakukan terhadap 40 responden. Responden tersebut di kelompokkan 20 responden untuk kelompok perlakuan terapi murottal dan kelompok kedua diberi perlakuan relaksasi dzikir. Data hasil penelitian tersaji dalam tabel sebagai berikut :

Usia responden pada kelompok terapi murottal $70 \%$ masuk usia reprodusksi sehat, sedangkan pada kelompok relaksasi dzikir prosentasenya lebih banyak yaitu $80 \%$.

Gravida responden tersebar dari primigravida dan multigravida. Multigravida tertua yang ikut menjadi responden adalah kehamilan keempat. Baik pada kelompok terapi murottal dan kelompok relaksasi dzikir prosentase terbanyak pada primigravida yaitu 
$45 \%$ pada kelompok terapi murottal dan 55\% pada kelompok relaksasi dzikir.

Data skor kecemasan sebelum dan sesudah dilakukan perlakuan pada kelompok yang diberikan perlakuan relaksasi dengan therapy murottal dan relaksasi dzikir pada 40 dapat dijelaskan bahwa hasil pretest kecemasan pada kelompok terapi murottal minimal 29 dan skor maksimal 41 dengan rata rata 35,65. Sedangkan hasil posttest skor kecemasan minimal 17 dan skor maksimal 28 dengan rata rata 20,55.

Pada kelompok relaksasi dzikir skor kecemasan, pretest minimal 26 dan skor maksimal 42 dengan rata rata 35,85 . Sedangkan hasil posttest skor minimal 13 dan skor maksimal 26 dengan rata rata 17,55.

Distribusi data diolah menggunakan Shapiro wilk test of normality karena responden tiap kelompok kurang dari 50 responden. Sebaran distribusi data skor pre test terapi murottal memiliki nilai $p>0,05$, dapat di simpulkan bahwa skor pre test terapi murottal memiliki distribusi data normal. Sedangkan data post test terapi murottal, pre test relaksasi dzikir, post test relaksasi dzikir masing-masing memiliki nilai $\mathrm{p}$ $<0,05$ sehingga disimpulkan ketiganya memiliki distribusi data tidak normal. Untuk itu uji statistic yang digunakan adalah uji statistic untuk distribusi data tidak normal.

Untuk mengetahui perbedaan sebelum dan sesudah dilakukan terapi murotal dilakukan uji statistic data berpasangan menggunakan Wilcoxon sebagaimna tersaji pada table 1.

Tabel 1. Uji Beda Skore Pretest Postest Kecemasan Pada Ibu Hamil Pre Eklampsia Ringan di Wilayah Puskesmas Baturraden tahun 2016

\begin{tabular}{llll}
\hline Perlakuan & Skore & $\mathrm{Z}$ & p-value \\
\hline Terapi Murottal & $\begin{array}{l}\text { Pretest } \\
\text { Postest }\end{array}$ & $-3,927$ & 0,0001 \\
\hline Relaksasi Dzikir & $\begin{array}{l}\text { Pretest } \\
\text { Postest }\end{array}$ & $-3,923$ & 0,0001 \\
\hline
\end{tabular}

Manfaat perlakuan terapi murottal dapat dilihat dari hasil uji statistic untuk skor pretest dan posttest. Nilai Z hitung sebesar 3,927 dengan arah negative dan $p$ value 0,0001 . Sehingga dapat disimpulkan terapi murottal dapat menurunkan skor kecemasan secara signifikan pada ibu hamil dengan preeclampsia.

Efektifitas perlakuan relaksasi dzikir dapat dilihat dari hasil uji statistic untuk skor pretest dan posttest. Nilai Z hitung sebesar 3,923 dengan arah negative dan $p$ value 0,0001 . Sehingga dapat disimpulkan relaksasi dzikir dapat menurunkan skor kecemasan secara signifikan pada ibu hamil dengan preeclampsia.

Kedua perlakuan yang di uji masing masing memberikan hasil yang signifikan dalam menurunkan tingkat kecemasan. Selanjutnya dilakukan uji untuk mengetahui perbedaan perlakuan terapi murottal dengan relaksasi dzikir.

Untuk menilai asumsi kecemasan dua kelompok perlakuan dilakukan uji beda nilai pretest. Didapatkan $p$ value 0,640 yang artinya tidak ada beda skore awal kecemasan pada kelompok relaksasi dzikir maupun kelompok terapi murottal. Sehingga untuk uji beda perlakuan digunakan nilai posttest.

Tabel 2 Uji Beda Efektifitas Relaksasi Dzikir Dengan Terapi Murottal DalamMenurunkan Kecemasan Pada Ibu Hamil Pre Eklampsia Ringan diWilayah Puskesmas Baturraden tahun 2016

\begin{tabular}{llll} 
Perlakuan & Mean rank & Z & p-value \\
& & & \\
\cline { 1 - 2 } Terapi Murottal & 25,72 & $-2,838$ & 0,004 \\
\hline Relaksasi Dzikir & 15,28 & & \\
\hline
\end{tabular}

Berdasar hasil uji menggunakan mann whitney test diketahui terapi murottal memiliki mean ranngking 25,72 sedangkan kelompok yang diberi perlakuan relaksasi dzikir memiliki mean rangking 15,28 . Pada nilai a $5 \%$, diperoleh p-value sebesar 0,004 maka Ho ditolak dan Ha diterima, sehingga secara statistic pada penelitian ini ada beda terapi murottal dengan relaksasi dzikir dalam menurunkan kecemasan ibu hamil dengan preeklampsia.

\section{Pembahasan}

Ada beberapa cara untuk menghindari efek negatif yang disebabkan oleh kecemasan yaitu dengan menggunakan tekhnik atau metode yang dapat menurunkan peningkatan hormon adrenalin di dalam tubuh ibu hamil pre eklampsia yang merupakan penyebab dari kecemasan. Metode tersebut adalah distraksi dan relaksasi, distraksi dan relaksasi merupakan metode untuk menghilangkan kecemasaan dengan cara mengalihkan perhatian pada hal lain sehingga pasien akan lupa terhadap cemas yang dialami sehingga seseorang dapat lebih tenang atau santai dalam menghadapi stresor. Stimulus sensori yang menyenangkan menyebabkan pelepasan endorfrin yang bisa menghambat stimulus cemas yang 
mengakibatkan lebih sedikit stimuli cemas yang ditransmisikan ke otak (Potter, 2005).

Beberapa penelitian menunjukkan hubungan antara coping religius dengan kecemasan yang turut menunjukkan pentingnya unsur spiritual dan religius dalam penanganan kecemasan. Pada penelitian ini telah dilakukan teknik terapi murottal dan relaksasi dzikir yang bertujuan untuk menurunkan kecemasan yang dialami oleh ibu hamil yang mengalami pre eklampsia.

Hasil uji statistic data yang diperoleh pada penelitian ini, ada perbedaan skor kecemasan dan rata-rata sebelum dan setelah dilakukan relaksasi dzikir serta sebelum dan sesudah dilakukan terapi murottal.

Hasil uji statistic juga diperoleh $p$ value 0,0001 yang artinya relaksasi dzikir berpengaruh terhadap penurunan skor kecemasan pada ibu hamil pre eklampsia ringan. Hasil penelitian tentang relaksasi yang digabungkan dengan bacaan dzikir mampu menimbulkan respon relaksasi sehingga dapat menurunkan kecemasan pada ibu hamil dengan pre eklampsia.

Relaksasi dzikir pada beberapa penelitian terbukti dapat menurunkan tingkat kecemasan. Seperti penelitian relaksasi dzikir yang dilakukan terhadap tingkat kecemasan pasien pre operasi bedah (Mardiyono, Angraeni, \& Sulistyowati, 2007). Hasil penelitian tersebut menunjukkan bahwa terapi dzikir sebagai teknik relaksasi psikologis efektif untuk menurunkan kecemasan dengan tingkat kecemasan, perasaan relax pada seluruh responden yang berjumlah 70 pasien pre operasi bedah. Hal ini sejalan dengan hasil penelitian ini bahwa dengan intervensi relaksasi dzikir dapat menurunkan kecemasan.

Seseorang yang sedang mengalami cemas, cenderung mengalami perubahan persepsi dan memiliki pikiran negatif terkait permasalah yang dihadapinya. Teknik pemusatan pikiran pada orang yang mengalami kecemasan dapat dilakukan melalui teknik relaksasi dzikir. Bacaan dzikir yang diulang-ulang merupakan salah satu cara untuk memusatkan pikiran seseorang terhadap makna dari kalimat dzikir. Kalimat dzikir sendiri mengandung makna positif, sehingga pikiran negatif yang dialami seseorang yang cemas akan digantikan dengan pikiran positif ketika orang tersebut berfokus pada kalimat dzikir (Patimah, 2015).

Pikiran positif akan menimbulkan emosi positif yang mampu merangsang kerja limbic untuk menghasilkan endorphine. Endorphine mampu menimbulkan perasaan euforia, bahagia, nyaman, menciptakan ketenangan dan memperbaiki suasana hati (mood) seseorang hingga membuat seseorang berenergi (Suryani, 2013)

Terapi murottal merupakan salah satu metode distraksi yang dilakukan dengan mendengarkan orang yang sedang melantunkan ayat suci Al Qur'an. Pada penelitian ini uji statistik skor kecemasan sebelum dan setelah dilakukan terapi murottal menunjukkan hasil $p$ value $<0,0001$. Nilai $p$ tersebut menunjukan bahwa terapi murottal mampu menurunkan kecemasan pada ibu hamil dengan pre eklampsia secara signifikan.

Hasil penelitian terapi murottal yang peneliti lakukan mampu menurunkan kecemasan yang dialami oleh ibu hamil dengan pre eklampsia sejalan dengan penelitian yang telah dilakukan sebelumnya oleh Handayani (2014) yang meneliti kecemasan pada ibu bersalin. Dalam penelitiannya terdapat rerata penurunan intensitas kecemasan ibu bersalin primigravida kala I fase aktif sebelum dan sesudah dilakukan terapi murottal.

Terapi suara mendengarkan bacaan Al quran mempunyai pengaruh yaitu berupa perubahan-perubahan arus listrik di otot, perubahan sirkulasi darah, perubahan detak jantung, dan kadar darah pada kulit. Perubahan tersebut menunjukkan adanya relaksasi atau penurunan ketegangan otot syaraf. Terapi ini bekerja pada otak, yang merangsang otak memproduksi zat kimiayang disebut neuropeptide, yang memberikan umpan balik berupa kenikmatan atau kenyamanan (Handayani, 2014).

Relaksasi dzikir dan terapi murottal pada penelitian ini mampu memberikan efek menurunkan tingkat kecemasan. Peneliti lakukan uji selanjutnya untuk mengetahui beda efektifitas relaksasi dzikir dan terapi murottal. Secara statistic terdapat perbedaan hasil posttest kedua perlakuan ini. Dengan menggunakan uji mann whitney didapatkan nilai $\mathrm{p} 0,004$ dengan beda mean relaksasi dzikir 15,28 sedangkan kelompok yang diberi perlakuan terapi murottal mean 25,72 . Dengan melihat beda mean pada penelitian ini, dapat disimpulkan relaksasi dzikir memiliki efektifitas yang lebih baik dalam menurunkan kecemasan.

Berdasarkan pada piramida pembelajaran Dale atau dalam bahasa Inggris lebih dikenal dengan dengan Cone of Experience oleh Edgar Dale (1946), bila peserta didik keterlibatannya diintensifkan dengan praktik efektifitas mencapai $70 \%$. Sedangkan bila keterlibatannya 
hanya mendengarkan, keefektifan baru mencapai $20 \%$. Teori ini dapat diamati pada hasil penelitian ini dimana responden yang melakukan aktivitas dzikir, dimana bibir, pikiran bekerja hasilnya lebih baik dibanding dengan yang hanya mendengarkan. Pada saat melakukan intervensi spiritual ini, responden dengan relaksasi dzikir dari segi aktivitas fisik lebih aktif dibandingkan dengan kelompok terapi murotal.

Keaktifan responden dalam melakukan terapi dzikir membuat responden merasa lebih dekat dengan Tuhan. Hal ini menurut Patimah (2015) disebabkan pula oleh makna yang terkandung dari kalimat dzikir. Makna tersebut merupakan bentuk kepasrahan seseorang terhadap Tuhannya, sehingga akan memunculkan harapan dan pandangan positif terhadap kehidupan serta memberikan ketenangan jiwa.

Berdasarkan hasil penelitian, responden yang mengalami kecemasan dengan relaksasi dzikir kecemasannya beranggsur angsur menurun. Hal ini didukung oleh penelitian Mardiyono, Anggraini, M., \& Sulistyowati D (2011) bahwa efek dari doa dan psikoterapi agama mampu meningkatkan kebahagiaan dan kesehatan fisik dan mengurangi kecemasan, serta depresi.

\section{Simpulan dan Saran}

Relaksasi dhikr mampu mengurangi kecemasan pada responden. Terapi murottal juga mampu mengurangi kecemasan responden. Relaksasi dhikr memiliki keefektifan yang lebih baik dalam mengurangi kecemasan dengan melihat p-value dan mean yang berbeda. Therapi yang intervensinya menuntut aktivitas sesuai dengan kemampuan mereka memiliki kekuatan dan motivasi internal yang kuat. Petugas kesehatan dapat mulai membimbing therapy ini bila menemui ibu hamil dengan pre eklampsia untuk menurunkan kecemasan yang dialami.

\section{Ucapan Terima Kasih}

Terimakasih banyak kami ucapkan untuk kesempatannya bisa mendapatkan dana Risbinakes DIPA Poltekkes Kemenkes Semarang, sehingga penelitian ini dapat terselesaikan. Ucapan terimakasih disampaikan kepada semua pihak yang ikut berpartisipasi dalam penelitian ini. .

\section{Daftar Pustaka}

Banyumas, D.K.K., Resume Profil Kesehatan Kabupaten Banyumas Tahun 2015. Banyumas, 2016

Bobak, Irene M. 2005. Buku ajar Keprawatan Maternitas Cetakan 1. Jakarta: EGC

Cunningham, F. Gary. 2005. Obstetri Williams Vol. 1, Edisi 21.Jakarta: EGC

Duckitt K. Risk Factor for Preeclampsia at Antenatal Booking,2006. Avaliable from: http://www.bmj.com. Diakses pada tanggal 12 Februari 2016

Handayani, R. Fajarsari, D, Asih, D. , Rohmah, DN. Pengaruh terapi murottal al-qur'an untuk penurunan nyeri persalinan dan kecemasan pada ibu bersalin kala i fase aktif. Jurnal Ilmiah Kebidanan, Vol. 5 No. 2 Edisi Desember 2014

Hawari, D(2007), Sejahtera di Usia Senja. Jakarta :Balai Penerbit FKUI

Hurlock, B Elizabeth (1980), Psikologi Perkembangan Edisi ke- 5. Jakarta : Erlangga

Isworo, A., Hakimi, M., Wibowo TA., Hubungan antara kecemasan dan kejadian preeclampsia. Berita Kedokteran Masyarakat Vol. 28, No 1 Maret 2012.

Jacob. 2009. Edgar Dale's Cone Of Experience [online]. Tersedia

di :http://www.slideshare.net/jacobsons ea/edgar-dales-cone-of-experience1.

[diakses pada tanggal 25 Oktober 2016).

Kemenkes RI., (2015) Pedoman ANC terpadu., Jakarta: Kemenkes

Manuaba I, Editor: Nuning Z, dkk. (2007) Pengantar Kuliah Obstetri, Ed. I, EGC, Jakarta.

Mardiyono, M., Songwathana, P., and Petpichetchian, W. (2011). Spirituality intervention and outcomes: Corner stoneof holistic nursing practise. Nurse Media Journal of Nursing, 1(1):117-127.

Mardiyono, Anggraini, M., \& Sulistyowati D (2007). Pengaruh terapi Zikir terhadap penurunan kecemasan pasien prabedah mayor. PDII-LIPI

Nursalam (2003). Konsep dan Penerapan Metodologi Penelitian Ilmu Keperawatan. Jakarta : Salemba medika

Patimah, I. Suryani, S. Nuraeni, A., Pengaruh relaksasi dzikir terhadap tingkat kecemasan pasien gagal ginjal. Jurnal Keperawatan Padjajaran Volume 3 Nomor 1 April 2015 
Pemprov Jawa Tengah, Profil kesehatan propinsi jawa tengah tahun 2014. Semarang, 2015

Potter \& Perry. (2006). Buku ajarfundamental keperawatan : konsep,proses dan praktek, volume 2. Jakarta: EGC.

Santjaka, A. (2011). Statistik untuk penelitian kesehatan. Nuha Medika Yogyakarta

Suliswati, dkk.(2005).Konsep Dasar Keperawatan Kesehatan Jiwa, EGC, Jakarta.

Suryani, (2013) Shalat and dhikr to dispel voices: The experience of Indonesian muslim with chronic mental illness: Malaysian Journal Publish Online Early.

Wahyu, R., Deswita. Pengaruh terapi murotal terhadap tingkat kecemasanmenghadapi persalinan pada ibu hamil.Ners Jurnal Keperawatan Volume 9, No 2, Oktober 2013.

Winkjosastro, Hanifa. (2005). Ilmu Kandungan Edisi 2 Cetakan Ke-4. Jakarta: YBP-SP. 